\title{
The Threats and Challenges of a Multipolar World: A Ukraine Crisis Case Study
}

\section{Oleksii Izhak}

National Institute for Strategic Studies (NISS), Dnepropetrovsk, Ukraine http://www.niss.gov.ua/

\begin{abstract}
As the post-cold-war unipolar system transforms into a polycentric one, it becomes more complex and less predictable. The new system may be crushed with less effort than needed to keep it on track. The polycentric international system, as it emerges, suffers from hybrid threats. They are difficult to identify and predict. Russia pioneered exploiting the new vulnerabilities to gain unilateral advantages. Russia's hybrid war against Ukraine was just a starting episode of her wider attempt to crush the whole world order. Responsible world powers have either to fix the vulnerabilities of the polycentric world, or to block malicious attempts to exploit it.
\end{abstract}

Keywords: Multipolar world, polycentric world, hybrid war, Ukrainian crisis, Russian policy.

\section{Introduction}

The crisis in and around Ukraine has clearly demonstrated that the world has changed. This is not news for the most observant politicians and researchers. The changes accumulated slowly, and many of the consequences were predictable. However, until very recently, our vision of the world has fit into the general mindset of a "post-Cold War" era. It is no longer a world of two superpowers, but neither has it become a world with only one center of gravity, nor one of multiple poles, having frozen in time, mid-transition. Then, Russia decided to present Ukraine with a list of claims in a way that pointed a large arrow to the 
past. In the words of Russian analyst Lilia Shevtsova, Russian President Vladimir Putin ended the global "interregnum." ${ }^{1}$

\section{Poles in a Pole-free World}

The basic idea behind the new world that has emerged was probably most aptly described five years ago by Richard Haass, who classified the new world order as "non-polar." Despite some similarity to the multi-polarity that existed prior to the First World War, today's centers of power are not "poles" in the fullest sense of the word, as the world's largest states once were: "States are being challenged from above, by regional and global organizations; from below, by militias; and from the side, by a variety of nongovernmental organizations (NGOs) and corporations." ${ }^{2}$ This vision has also been called a "polycentric" world. It is most fully described in the work, "Global Trends 2030: Citizens in an Interconnected and Polycentric World," ${ }^{3}$ in which the key points coincide with those proffered by Haass.

Meanwhile, futurologists predicted a technological revolution that will fundamentally change the world, but this is still far-fetched. 3D printing has yet to overturn industrial manufacturing, cyberspace has not yet expanded to the extent it could, fuels are not yet harvested from other planets, medicine is still limited in the face of many lethal illnesses, biotechnologies are not yet flooding the world with food, and no solution has been found to counter climate change. Nevertheless, there is already a vision of how all this could take place in the foreseeable future.

The technological revolution aside, it is now possible to see how the rough contours of a polycentric world appeared earlier than researchers expected, which brings with them additional threats and challenges. The multipolar world that preceded WWI and the bipolar world that formed after WWII were absolute in the sense that the polarized spaces around each center were directly adjacent, with minimal neutral zones. The threats were predictable, and the reactions to them could be computed rationally. These can be described as traditional threats. The collapse of the bipolar system after the end of the Cold War turned the world, briefly, into a monopolar system. However, the strength of the American pole rapidly lost its absolute quality. New and growing centers of power suddenly appeared, each hoping to become a new pole. In turn, dur-

1 Lilia Shevtsova, "Putin Ends the Interregnum," The American Interest, 28 August 2014, available at http://www.the-american-interest.com/shevtsova/2014/08/28/ putin-ends-the-interregnum (accessed 31 August 2014).

2 Richard N. Haass, "The Age of Nonpolarity," Foreign Affairs 87:3 (2008), available at www.foreignaffairs.com/articles/63397/richard-n-haass/the-age-of-nonpolarity (accessed 31 August 2014).

3 "Global Trends 2030: Citizens in an Interconnected and Polycentric World," European Strategy and Policy Analysis System (ESPAS) (European Union Institute for Security Studies, March 2012), available at http://www.iss.europa.eu/uploads/media/ ESPAS_report_01.pdf (accessed 31 August 2014). 
ing this transitional period, new threats also appeared. The list is long, extended further by the multiple facets of globalization. Some of these are reflected in states and international organizations, in the institutions and policies dedicated to security. For example, at the Lisbon Summit in 2010, NATO listed terrorism, the proliferation of WMD, cyberattacks, and natural disasters as key areas of its activity.

Traditional and new threats did not vanish with the advent of a polycentric world, but the conditions in which they appeared became qualitatively different. Spaces that were weakly structured around poles, or not polarized at all, became a systemic component. In such spaces there are centers of gravity of varying weights, the actions of which add dynamism to the global system in the absence of global management. The very concept of a new world order now has new meaning. Order exists as a manifest phenomenon, with its own, internal laws, but it exists as a system of rational management. Figuratively speaking, it is a motley fleet of ships, boats, and rafts, linked by ropes of varying strength, seized by an almost invisible seaward current that may lead to new shores, or lethal whirlpools. Nobody knows how to pick up the slack and articulate interconnections so that the fleet can become manageable and deliberately select its own course.

Returning to Haass' definition of a nonpolar world, a more precise delineation would be helpful, as the world is "weakly polar." There are poles, but they are not absolute, and they compete with centers of gravity of varying weights. The poles differ from the centers in terms of the degree of concentration of influence and power, and whether it is economic, political, military, or ideological. There are many centers of different types, with one or another resource at their disposal. Yet only poles connect different domains of power; they are still identical to states and groups of states.

It is hard to deny that the USA, the EU, China, and Russia are poles, but they do not have absolute influence. Corporations, international organizations, NGOs, and religious bodies-even unrecognized states-possess their own domains of influence and sometimes clearly hope to become new poles in their own right. The fields of power and influence emanating from poles and centers intersect one another and interconnect in an intricate fashion, transforming the problem of global management into a new challenge to international security.

\section{The Ukraine Crisis: The Western Dimension}

Descending from abstract theory to the situation on the battlefields of Eastern Ukraine, it is already possible to observe the concrete manifestations of some aspects of the polycentric world. Prima facie, the Ukrainian crisis fits into familiar categories: the separatism supported from abroad and the "regime change" toolbox are at play. However, closer analysis reveals Russia's effort to utilize the weaknesses of this polycentric world to reestablish itself as one of the poles. This is an effort that has global consequences. 
Russia's foreign policy concept states that "international relations are going through a transitional period, the nature of which is the formation of a polycentric international system." ${ }^{4}$ The formation of this system is not just taken as a given - it is Russia's desired end state. Russian Foreign Minister Sergei Lavrov recently stated: "The fact that the crisis in Ukraine is one of the manifestations of the pains in which a truly polycentric world is born." ${ }^{5}$ According to Russian logic, that country - through its actions towards Ukraine-is building a polycentric world, while the West is hindering it in order to "artificially slow down the advent of this multi-polar and polycentric world, which is the objective result of trends in world development." 6

Russia's obsession with the idea of a polycentric world stems from the idea that, given its decentralized nature, it will be easier for Russia to realize its ambitions as a pole, expanding both power and influence, even if such expansion will be steeped in blood, human suffering, and economic losses. This is the negative reading of the new opportunities. At the applied level, the reason behind Russia's actions was laid out in early 2013 by Valery Gerasimov, head of the Russian General Staff, as follows:

In the methods of resistance used, the emphasis is shifting towards broad use of political, economic, information, humanitarian and other non-military measures, implemented together with the protest potential of the population. All this is complemented with covert military methods, including informational warfare measures and special forces' operations. The overt use of force is often adopted under the guise of peacekeeping operations and crisis regulation only at a certain stage, usually to ensure that success in a conflict is absolute.

This extract, which has been widely cited, is interesting for a number of reasons. Gerasimov spoke about the experience of the Arab Spring, but as is evident from this and other of his statements, he interpreted that phenomenon in the spirit of contemporary Russian conspiracy theories. The main thesis is that "color" revolutions and other political cataclysms are a new form of warfare conducted by the USA and the West in general, in which the target is Russia, with its "constructive" political regime and "untold" natural resources.

4 Ministry of Foreign Affairs of the Russian Federation, "The Foreign Policy Concept of the Russian Federation, approved by RF President V. V. Putin on 12 February 2013," available at www.mid.ru/brp_4.nsf/0/6D84DDEDEDBF7DA644257B160051BF7F (in Russian) (accessed 31 August 2014).

5 "Lavrov: The Ukraine Crisis is one of the birthing pains in which a polycentric world is born," Oko planety, 11 April 2014, available at http://oko-planet.su/politik/ politiklist/238618-lavrov-krizis-na-ukraine-odno-iz-proyavleniy-teh-muk-v-kotoryhrozhdaetsya-policentrichnyy-mir.html (in Russian) (accessed 31 August 2014).

6 "US and EU hinder Russian actions in preventing global threats," FOCUS News Agency, 27 August 2014 (accessed 31 August 2014).

7 Valery Gerasimov, "The value of science is prediction. New threats demand rethinking the ways and means of conducting warfare," Voenno-promyshlenniy kurier, 27 February 2013, available at http://www.vpk-news.ru/articles/14632 (in Russian) (accessed 31 August 2014). 
In Russia, and not only amongst the leadership, but also in mass consciousness, the conflict with Ukraine is seen as a "just" response to the actions of the USA. Some of the Russian arguments could even be worthy of attention, if not for the following circumstance: the way that Russia acted in Ukraine forced the degradation of the ideology, politics, and economy at each new stage of conflict escalation. Initially, the Russian information space favored the thesis that a "fascist junta" had come to power in Kiev. This could be called a curiosity of the information war, if not for the scale of the propaganda undertaken. Most of the Russian population, a significant portion of the population of occupied Crimea and the Eastern regions of Ukraine, was convinced that as a result of Western actions in Ukraine, fascism had raised its ugly head again and that Ukraine had "vanished" as a state, while Russia, as a result, had every right to use all tools available to neutralize the threat. The demonization of one's enemy has been seen in the history of the Western press, but the extent of the propaganda is important here. Russia's perception of the authorities in Ukraine is comparable only to how the Western information space would respond to a foreign body deserving as much hatred as Hitler, Milošević, Hussein, Gaddafi, and Kim Jongun, all in the same person - and if it were also claimed that such a monster regime was created by Russia.

The "success" of this destructive information campaign and Russia's subsequent steps to escalate the conflict taken cannot be explained merely as a state monopoly and rigid, centralized management. Commercial PR agencies were widely used, as well as public organizations and financial and industrial holdings with a "patriotic orientation." The military portion of the operation to annex Crimea was the work of so-called "little green men" or "polite people" (wellequipped soldiers with no insignia) and organized by the Russian Defense Ministry and special services. Yet the social and political element was the neutralization of pro-Ukrainian forces, "switching" local authorities from Kiev to Moscow, organizing a referendum - all this was implemented with the aid of organized structures and finances from one of the major Russian financial and industrial groups. Then, a combined "strike group" composed of PR experts, midlevel politicians, administrators, and "dogs of war"-all reinforced with resources looted from Crimea, including seized weapons-was dispatched to Eastern Ukraine, ${ }^{8}$ after the area had been "warmed up" through the mass media and flash mobbing by street fighters (the so-called "Russian Spring"). When the "blitzkrieg" failed, Russia was forced into a military escalation that, by the end of summer 2014, led to the deployment of regular Russian troops, again without insignia.

Although Russia has the right to have its arguments heard, the methods that it uses to enforce their validity place their reasoning in doubt. Westerners

8 Oleg Kashin, "From Crimea to the Donbass: the adventures of Igor Strelkov and Aleksandr Borodaya," Slon, 19 May 2014, available at http://slon.ru/russia/iz_kryma_v_ donbass_priklyucheniya_igorya_strelkova_i_aleksandra_borodaya-1099696.xhtml (in Russian) (accessed 31 August 2014). 
mindful of "Realpolitik" quite rightly indicate Russia's natural reflexes with respect to expansion by NATO and the EU, and the Westernization of neighbors: "Imagine the fury in Washington, if China was building a powerful military alliance and attempting to include both Canada and Mexico." ${ }^{9}$ Hence, the conclusion that Ukraine must be turned into a second Finland in order to resolve the current crisis, including not only military, but also economic and social aspects of forced neutrality.

The idea is not unworthy of attention, and could find resonance in Ukraine, if not for a number of caveats. Before the crisis in relations with Russia, and even in the initial stages thereof, nobody in Ukraine seriously discussed NATO membership. The non-aligned status of the country had been set in legislation. In 2008 NATO refused to offer Ukraine the Membership Action Plan (MAP), in line with the actual moods in Ukrainian society and amongst the elite. The idea of membership was supported only by a small minority (about $15 \%$ ). Russia's reaction to the EU's Association Agreements with Ukraine approached hysteria, and in the summer of 2013-long before signing-the hysteria had triggered trade sanctions, in an echo of the earlier reaction in 2008 , to the possibility that a MAP could be on the table. Then, Russia told Ukraine that if Ukraine was denied NATO membership, it would be able to develop an economic partnership with the EU in parallel to simultaneously partnering with Russia. But when this question reached the practical implementation stage, it turned out that the EU, in Russia's view, was "Sodom and Gomorrah," greedily plotting to swallow Ukraine simply to spite Russia. While many consider this to be an exaggeration, even the most cursory review of the Russian information space reveals that this is, more likely, an understatement of how Russian interests are rationalized within the country itself.

Ukraine's experience is that no concessions to Russia are ever enough, and there is no stable status quo that does not rob the country of its identity. This is the core problem with establishing solid, friendly relations. The first episodes of Russian "saber-rattling" with respect to Ukraine took place as early as the early 2000s, when President Leonid Kuchma's administration was very far from any actual rapprochement with NATO and the EU. Here it is worth remembering that Russia, without any warning, built a damn connecting it to a Ukrainian island in the Kerch Strait, where a Ukrainian border post was located, and subsequently explained the incident as "the initiative of the local authorities" and the unexpected dislocation of troops to a Crimean military compound, and further as exercises and technical difficulties without notifying Ukraine in advance. Then, Ukraine tended to turn a blind eye and disregard such incidents. Later, the gas wars began against the "orange" government, which made loud declarations about NATO and EU membership, although it had not taken any concrete steps. When Viktor Yanukovych came to power in 2010, a short renais-

9 John J. Mearsheimer, "Why the Ukraine Crisis Is the West's Fault," Foreign Affairs 93:5 (2014), available at http://www.foreignaffairs.com/articles/141769/john-jmearsheimer/why-the-ukraine-crisis-is-the-wests-fault (accessed 31 August 2014). 
sance began due to Ukraine's unilateral concessions on humanitarian, political, and military issues, including the declaration of a non-aligned status and an extension of leases for the Black Sea Fleet. However, as early as 2011 and long before the talks on EU Association Agreements had concluded, a cooling-off began as Russia discovered Ukraine's reluctance to engage in "genuine integration," which was actually understood as the formation of a single state. The trade war in 2013 was the final stage of this deterioration. This illustrates the notion that Russia is not satisfied with turning Ukraine into a second Finland, regardless of the political hints and messages it may disseminate through the media or diplomatic channels. Russia can tolerate Ukraine as an independent state only with the same status as Belarus, but no more than that. The very existence of Ukraine is viewed by the Russian elite as "geopolitical aggression" by the West. Golda Meir coined a phrase applicable not only to Israel, but also to Ukraine today: "We want to live. Our neighbors want to see us dead. This does not leave much space for compromise." 10

Returning to the realm of theory, it is possible to demarcate a broader attempt by Russia to establish itself as a pole by using the vulnerability of the polycentric world that appeared, in this case, with respect to Ukraine. In 2013, Ukraine found itself in desperate financial straits and was approaching a default. The Yanukovych administration's maneuvers between the EU and Russia intended to rapidly obtain foreign aid. According to one assessment, Ukraine ended up in this situation due to changes in the global financial markets, following policy changes by America's Federal Reserve System. ${ }^{11}$ There was no malicious intent aimed against Ukraine here - Ukraine was simply unlucky. The Ukrainian authorities subsequently took steps that triggered an acute internal crisis, which in 2014 led to total political upheaval. Russia perceived a threat from these events, but also an opportunity. In March it annexed Crimea, which allowed the Russian authorities to resolve many domestic problems, including the total marginalization of all opposition and redirection of social dissatisfaction towards Ukraine. Even if the initial assessment of the impact of the Federal Reserve System's actions prompts doubts, it illustrates how events can develop in a polycentric world without global management.

These events inspired Russia to build even more ambitious plans. A mass of statements and actions suggest a general plan that has not been declared officially: to create a chain reaction to tear apart Ukraine (without using military force when possible, but using force whenever necessary), provoking a schism within the EU on the Ukraine issue, disrupting plans to build a free trade zone between the USA and the EU, and isolating the USA from the European continent. The arsenal of resources brought to fruition is of interest, given its great

10 "Goldele Mabovich' dream," available at http://www.freie-juedische-meinung.de/ portraits/438-2013-05-02-19-17-17 (in Russian) (accessed 31 August 2014).

11 Gideon Rose and Benn Steil, "Foreign Affairs Focus: Benn Steil on Fed Policy," Foreign Affairs, 2 August 2014, available at www.foreignaffairs.com/discussions/audiovideo/foreign-affairs-focus-benn-steil-on-fed-policy (accessed 31 August 2014). 
range and the creativity behind it. Very powerful and effective propaganda resources were deployed and marginal political forces and individual politicians of influence were "incentivized" also in Europe and the USA, while public structures and economic agents were engaged, militarized "popular uprisings" were organized, and, finally, military units without insignia were deployed. The main approach for organizing this arsenal could be loosely labelled "public-private partnerships," following the PPP model so popular in the West, except for the malicious intent at the core of this ambition. It would be erroneous to consider the Russian attack on the West as merely the actions of the special services and armed forces. Russian policies enjoy considerable domestic support and a mass of volunteers in state structures and business, which possess their own tools, used to achieve common goals. The conflict with Ukraine was just a part of this broad attack, and Russia made full use of the vulnerabilities of the polycentric world.

The consequences of this offensive are well known: NATO has been given a new raison d'être laid out down on paper with the outcomes of the Wales Summit and the EU Association Agreements with Ukraine are signed and await ratification, while Russo-Ukrainian relations have become antagonistic. In the West, the poles have come into contact again like during the Cold War. Numerous areas of ambiguity have been localized in one key issue: whether Ukraine will withstand the new wave of tension, and what compromises it will adopt in a bid for self-preservation.

\section{The Crisis in Ukraine: The Eastern Dimension}

The Ukraine crisis has produced certain consequences on the Eastern front: in Transcaucasia, in Central Asia, and in the Far East. The mechanisms for these changes are many and varied, and cannot be clearly structured, just like the polycentric world itself. The effect is complex, and promises even greater tension. Even without this malicious intent from any side, the concentration of tension in points of vulnerability in a polycentric world can trigger the formation of threats.

The Russian Caucasus has been drawn into the Ukraine crisis if only due to the fact that the main brunt of the Russian forces in Ukraine was put together from so-called national battalions in military units in Russia's Southern Operational Command. This group faced the majority of the human losses on the Russian side during the initial stages of military action in Eastern Ukraine. Relations between the Slavic population of Russia and residents of the Caucasus are complex. In recent years, they have often spilled over into large-scale social clashes along ethnic lines. The Russian leadership has found ways to quickly deflect internal conflict, redirecting it against the Slavic population of Ukraine. However, the conflict now threatens to return to Russia through the border with Ukraine - which Russia itself rendered porous. An important aspect is that in Chechnya, formerly the most prominent separatist republic in Russia, there is another conflict that has also been pushed across the border. In Ukraine, Russia 
is supported by the so-called "Kadyrovtsy" fighters - supporters of Ramzan Kadyrov, the Chechen president, who is loyal to the Russian leadership (thanks to generous financial injections). At the same time, Ukraine has been supported by divisions consisting of Chechens still loyal to the ideas of the late president, Dzhokhar Dudayev. They are in the minority, but under certain conditions they would be prepared for aggression against their motherland. In this case, the Caucasus could explode once more.

In Transcaucasia there are three frozen conflict zones: South Ossetia, Abkhazia and Nagorno-Karabakh. Political processes in Georgia exclude attempts to aggravate relations with Russia over South Ossetia and Abkhazia for the foreseeable future. However, in Nagorno-Karabakh escalation is possible. Azerbaijan's position is uncompromising: sooner or later sovereignty over NagornoKarabakh must be reestablished. Azerbaijan's economic and military might is constantly growing, and offset only by a convenient line of defense in NagornoKarabakh, Russian economic aid to Armenia, and the placement of a Russian military base on its territory. If Russia gets bogged down in the Ukrainian conflict, and proves to be weakened by international sanctions, Azerbaijan may yet get the chance to resolve the problem by force. A recurrence of the conflict already took place in July/August 2014. So far, it has been suppressed by Russian diplomatic interventions.

The chain of interrelations stretches from Nagorno-Karabakh to Central Asia. Attempting to disrupt the EU's Eastern Partnership program on all fronts (this was one of the episodes in the development of the crisis around Ukraine), last year Russia convinced Armenia to reject association with the EU in favor of membership in the Eurasian Economic Community (EurAsEc). This triggered additional disagreements between Russia and Kazakhstan. The latter, with partnership relations with Azerbaijan, insists that if Armenia joins the common customs space, Nagorno-Karabakh should not be included in that space. Such membership conditions are hard for Armenia to accept. The Ukraine crisis has even further exacerbated the contradictions within EurAsEc. Kazakhstan's position on the issue of deeper integration with Russia has become more cautious. All references to possible political integration were removed from the Agreement creating EurAsEc, which was signed at the end of May 2014. Kazakhstan, together with Belarus, blocked Russian attempts to introduce coordinated trade sanctions against Ukraine. Moreover, Kazakhstan openly declared that it saw no economic threats for EurAsEc stemming from Ukraine signing Association Agreements with the EU, though Russia insisted that these existed.

The situation worsened even more at the end of August 2014 as a result of a clumsy comment by Putin about Kazakh President Nursultan Nazarbayev: "He created a state in a territory in which there had never been a state. The Kazakhs did not have statehood." ${ }^{12}$ Previously, only lower-level Russian politicians

12 “Putin answered the Kazakhstan question," Tengri News, 29 August 2014, available at http://tengrinews.kz/sng/putin-otvetil-na-vopros-o-kazahstane-260975 (in Russian) (accessed 31 August 2014). 
had mentioned doubts about Kazakh statehood. A fairly major scandal ensued, as did a counter-reminder by Nazarbayev with respect to EurAsEc: "Astana will never join organizations that threaten Kazakh independence." ${ }^{13}$ In this case, the motivations of Russian politicians in provoking Kazakhstan against the backdrop of the Ukrainian crisis - be they malicious or careless - are not as important as the fact that tension in polycentric links is sufficiently acute to trigger a new crisis.

The exacerbation of the situation in EurAsEc due to the Ukrainian crisis has subsequently impacted relations with the Shanghai Cooperation Organization (SCO). For Russia, Chinese neutrality in the Ukraine issue is important, as for Russia this is paramount to direct support. However, the effect of SCO activity in Central Asia produces a growth in Chinese influence, leading to a reduction in Russian influence. China is overtaking Russia both in terms of trade turnover and investment in the region. Moreover, Russian influence is linked to an exacerbation of disagreements between Uzbekistan, Kyrgyzstan, and Tajikistan on the so-called hydroelectric issue. ${ }^{14}$ Moreover, Turkmenistan has virtually escaped Russia's grip. The growth of Chinese influence has now spread to all the countries of the region and is, so far, not generating conflicts.

A careful review of the situation in Central Asia reveals two important aspects. First, a like-for-like comparison of the trade turnover of each country in the region with external players shows impressive imbalances. For example, in the customs statistics for China and Kyrgyzstan for the same flow of goods, one country had figures several times greater than the other. ${ }^{15}$ Recently, these differences have levelled out, but they still remain too great to be explained by calculations alone. Statistical data on the trade turnover between Kazakhstan and Russia also show a large gap of more than $10 \%$ in 2013 (USD 23.8 billion according to Kazakh statistics ${ }^{16}$ and USD 26.5 billion according to Russian data.) ${ }^{17}$ This indicates a large volume of "grey" trade in Chinese goods with Kazakhstan and Russia through Kyrgyzstan. Plans for Kyrgyzstan to join EurAsEc only exacerbate the problem.

13 "Nazarbaev announced Kazakhstan may exist the Eurasian Union," Ak Zhayyk, 31 August 2014, available at http://azh.kz/ru/news/view/22768 (in Russian) (accessed 31 August 2014).

14 Uzbekistan perceives Russian investment in hydroelectric power in Kyrgyzstan as well as military aid to Kyrgyzstan and Tajikistan as a threat from the viewpoint of access to water resources and resolving border disputes.

15 Nurbek Toktakunov, et al., "Mirror statistics of the Kyrgyz Republic, 2008-2012" (Bishkek, 2014) (in Russian).

16 "The Foreign Trade Turnover of the Republic of Kazakhstan," available at http://www.stat.gov.kz/get/mg?id=ESTAT084715 (in Russian) (accessed 31 August 2014).

17 "Russian Foreign Policy with CIS countries," available at http://www.gks.ru/free_ doc/new_site/vnesh-t/vnt-sng.xls (in Russian) (accessed 31 August 2014). 
Second, Russia retains immense sectoral influence in the region due to its labor migrants. Their remittances from Russia make up a large part of the GDP of Tajikistan, Kyrgyzstan, and Uzbekistan. Dependency is a critical issue for Tajikistan: Russia could hurt its economy by simply prohibiting personal remittances (see Table 1).

Table 1. Assessment of the Regional Countries' Dependence on Russia regarding Labor Migration.

\begin{tabular}{lcccccc}
\hline Countries & $\begin{array}{c}\text { Transfers } \\
\text { from Rus- } \\
\text { sia, in mil- } \\
\text { lions of } \\
\text { USD }\end{array}$ & $\begin{array}{c}\text { \% } \\
\text { of GDP }\end{array}$ & $\begin{array}{c}\text { \% of Rus- } \\
\text { sian GDP }\end{array}$ & $\begin{array}{c}\text { Migrants } \\
\text { in Russia, } \\
\text { in mil- } \\
\text { lions }\end{array}$ & $\begin{array}{c}\text { \% of pop- } \% \text { of pop- } \\
\text { ulation }\end{array}$ & $\begin{array}{c}\text { ulation of } \\
\text { Russia }\end{array}$ \\
\hline Uzbekistan & 6633 & $11.68 \%$ & $0.32 \%$ & 2.58 & $8.53 \%$ & $1.80 \%$ \\
Tajikistan & 4155 & $48.84 \%$ & $0.20 \%$ & 1.18 & $14.35 \%$ & $0.82 \%$ \\
Kyrgyzstan & 2080 & $28.78 \%$ & $0.10 \%$ & 0.58 & $10.09 \%$ & $0.40 \%$ \\
Kazakhstan & 455 & $0.20 \%$ & $0.02 \%$ & 0.55 & $3.24 \%$ & $0.38 \%$ \\
Turkmenistan & 40 & $0.10 \%$ & $0.00 \%$ & 0.23 & $4.39 \%$ & $0.16 \%$
\end{tabular}

Note: calculations were performed based on data from the Russian Central Bank, Russia's Federal Migration Service and the World Bank. GDP was calculated at current USD exchange rates according to statistical data from 2013.

This means that by losing to China in trade and investment in Central Asia, Russia still has the option of negative influence: the ability to create a powerful crisis in the region, which would devalue China's growing impact. Russia does not have clear reasons to act in such a manner, but there can be no doubt of the level of Russian resolve if at any point China decides to utilize the weakening of its position due to the Ukraine crisis and Western sanctions.

From Central Asia, the effects of the Ukraine crisis extend into Russian policy with respect to Iran and the Far East. Russia has long supported Iran on the issue of Western sanctions. However, the recent progress on talks on the nuclear program, which since November of 2014 have threatened a long-term agreement and Iran coming out of isolation, coincided with the development of the Ukraine crisis. Iran entering global oil and gas markets implies a direct threat to Russia, given its economy's critical dependence on energy prices worldwide. Without having good cause or an opportunity to hinder the positive development of the talks on the Iranian nuclear program, Russia attempted to 
link large volumes of Iranian oil to barter operations. Long-winded negotiations ensued on annually bartering around 25 million tons of Iranian oil in exchange for supplies of Russian products. So far, these talks have culminated only in the signing, in early August 2014, of a very modest memorandum on the barter of around 2.5 million tons of oil annually. ${ }^{18}$ Russian interests in Ukraine thus proved to be connected to interests in the Iranian sphere.

In the Far East, the Ukraine crisis has also prompted a certain level of redistribution of forces. Japan, which has a territorial dispute with Russia, supported the Western sanctions. South Korea has maintained neutrality. China, as was mentioned, has rendered discreet support in order to pursue its own goals: the Ukraine conflict weakens Russia and the West, leaving more room for China to maneuver. North Korea is aligned with Russia, though Russia can barely expect to get much traction from this, aside from the opportunity to exert more negative influence on the situation by escalating the conflict around the North Korean nuclear and missile program.

Generally speaking, the Ukraine conflict's influence in the East does not appear as deep as it is in Europe. However, tension over a wide variety of issues has increased and, given a certain configuration of circumstances, unexpected predicaments could emerge. This analysis illustrates the variety of vulnerabilities of a polycentric system of relations and the possibility that crises could arise as a result of a geographically remote conflict.

\section{Conclusion}

The accelerated formation of a new system of international relations due to the crisis around Ukraine, which can be characterized fairly accurately as a polycentric world, has led to both new threats and challenges. The threats, which are usually considered to be of a traditional nature (war with the use of weapons), as well as new, detrimental technological developments, globalization, and climate change, have not vanished. However, a further threat has emerged: the absence, or at least a deficit, of global management; yet another threat is the possibility that the vulnerabilities of a polycentric world may be deliberately utilized.

The Ukraine crisis has demonstrated that a diversified system of relations that enables development could rapidly deteriorate into a Cold War situation. It appears that ordinary phenomena, such as minor economic and political clashes between the centers of power, internal political processes in individual countries, adjustments of the global financial system, and changes in oil prices are all capable of bringing about a momentary concentration of contradictions, in this case around Ukraine. At a certain point, Russia perceived internal political processes in Ukraine as a threat to its interests (this perception was the re-

18 "Iranian Barter. Russia and Iran have signed an oil supply contract," BFM, 7 August 2014, available at http://www.bfm.ru/news/268124 (in Russian) (accessed 31 August 2014). 
sult of internal processes within Russia itself) and decided to not simply protect itself, as it understood the concept, but also to make use of the vulnerabilities of the new international system of relationships for a large-scale redistribution of power and influence. This escalation triggered the return of a situation similar to the bipolar standoffs of the Berlin, Korea, and Cuban crises.

In the Caucasus, Central Asia, and the Far East, the Ukraine crisis has not triggered such significant changes. Nevertheless, a wide range of different interconnections have been subject to tension. As malicious interests appear, this tension could be released to form new conflicts, which may have no apparent connection to the events in Ukraine.

In a polycentric world, both positive and negative processes are accelerated. This means that local instability can rapidly lead to a concentration of diverse threats. Even if they are thoroughly studied individually and even if response mechanisms were identified in recent years, the rate at which they appear and the degree to which they manifest at any given time imply a new threat, which is unique to a polycentric world. This can be defined as the imminent instability of development.

It is difficult to offer any form of recommendation of how to act in the situation prior to the conclusion of the Ukraine crisis - perhaps the first crisis to fully embody the predicament described above. It is most probable that Ukraine will not only survive, but also remain capable of development as a democratic country with a fast-growing economy. This implies that measures will have to be taken to preserve the stable development of the polycentric world and prevent a roll-back to the old relationship models.

\section{About the author}

Oleksii Izhak is Deputy Director of the National Institute for Strategic Studies (NISS), Regional Branch in Dnepropetrovsk. Before starting his career at the NISS he worked in the defense industry. In the current position his main responsibility is preparing analysis on security issues for state bodies of Ukraine. He has published widely on security issues and international relations in Ukrainian professional journals and periodicals. 


\section{Bibliography}

Gerasimov, Valery. "The value of science is prediction. New threats demand rethinking the ways and means of conducting warfare." Voenno-promyshlenniy kurier (2013), http://www.vpk-news.ru/articles/14632.

Global Trends 2030: Citizens in an Interconnected and Polycentric World. European Union Institute for Security Studies, European Strategy and Policy Analysis System Report, 2012, http://www.iss.europa.eu/uploads/media/ ESPAS_report_01.pdf.

Goldele Mabovich' dream, 2014, http://www.freie-juedische-meinung.de/ portraits/438-2013-05-02-19-17-17.

Haass, Richard N. "The Age of Nonpolarity", Foreign Affairs 87, no. 3 (2008), www.foreignaffairs.com/articles/63397/richard-n-haass/the-age-of-nonpolarity.

Iranian Barter. Russia and Iran have signed an oil supply contract. BFM, 2014, http://www.bfm.ru/news/268124.

Kashin, Oleg. From Crimea to the Donbass: the adventures of Igor Strelkov and Aleksandr Borodaya. Slon, 2014, http://slon.ru/russia/iz_kryma_v_donbass_ priklyucheniya_igorya_strelkova_i_aleksandra_borodaya-1099696.xhtml.

Lavrov: The Ukraine Crisis is one of the birthing pains in which a polycentric world is born. Oko planety, 2014, http://oko-planet.su/politik/politiklist/ 238618-lavrov-krizis-na-ukraine-odno-iz-proyavleniy-teh-muk-v-kotoryhrozhdaetsya-policentrichnyy-mir.html.

Mearsheimer, John J. "Why the Ukraine Crisis Is the West's Fault." Foreign Affairs 93, no. 5 (2014), http://www.foreignaffairs.com/articles/141769/john-jmearsheimer/why-the-ukraine-crisis-is-the-wests-fault.

Nazarbaev announced Kazakhstan may exist the Eurasian Union. Ak Zhayyk, 2014, http://azh.kz/ru/news/view/22768.

Putin answered the Kazakhstan question. Tengri News, 2014, http://tengrinews.kz/sng/putin-otvetil-na-vopros-o-kazahstane-260975.

Rose, Gideon, and Benn Steil. "Foreign Affairs Focus: Benn Steil on Fed Policy." Foreign Affairs(2014), www.foreignaffairs.com/discussions/audio-video/foreignaffairs-focus-benn-steil-on-fed-policy.

Russian Foreign Policy with CIS countries, 2014, http://www.gks.ru/free_doc/ new_site/vnesh-t/vnt-sng.xls.

Shevtsova, Lilia. Putin Ends the Interregnum. The American Interest, 2014, http://www.the-american-interest.com/shevtsova/2014/08/28/putin-ends-theinterregnum. 


\section{Oleksii Izhak, Connections QJ 15, no. 1 (2016): 33-44}

The Foreign Policy Concept of the Russian Federation, approved by RF President V. V. Putin on 12 February 2013. Ministry of Foreign Affairs of the Russian Federation, 2013, www.mid.ru/brp_4.nsf/0/6D84DDEDEDBF7DA644257B160051BF7F.

The Foreign Trade Turnover of the Republic of Kazakhstan, 2014, http://www.stat.gov.kz/getlmg?id=ESTAT084715.

Toktakunov, Nurbek. Mirror statistics of the Kyrgyz Republic, 2008-2012. Bishkek, 2014.

US and EU hinder Russian actions in preventing global threats. FOCUS News Agency (2014). 